\title{
PENGARUH MOTIVASI EKSTRINSIK TERHADAP KINERJA PERAWAT PELAKSANA DALAM PENDOKUMENTASIAN ASUHAN KEPERAWATAN DIRUANG RAWAT INAP RUMAH SAKIT PERMATA BUNDA MEDAN TAHUN 2018
}

\section{The Influence Of Extrinsic Motivation On Nursing Performance Of Implementation In The Number Of Nursing Association In The Permata Bunda Hospital In 2018}

\author{
Wahyu Bima Saputra ${ }^{1}$, Juanita ${ }^{2}$, Siti Saidah Nasution ${ }^{3}$ \\ ${ }^{1}$ Fakultas Ilmu Kesehatan Masyarakat, Universitas Sumatera Utara \\ ${ }^{2}$ Fakultas Ilmu Kesehatan Masyarakat, Universitas Sumatera Utara \\ ${ }^{3}$ Fakultas Keperawatan, Universitas Sumatera Utara
}

\begin{abstract}
Abstrak
Kinerja perawat merupakan pelaksanaan tugas profesi yang dilaksanakan sesuai standar. Perawat tidak hanya melakukan asuhan keperawatan, tetapi melaksanakan dokumentasi asuhan keperawatan yang merupakan kinerjanya. Perawat pelaksana kurang memahami pentingnya pendokumentasian asuhan keperawatan, ini terlihat dari pendokumentasian yang tidak dilengkapi perawat. Tujuan penelitian ini adalah untuk mengetahui pengaruh motivasi terhadap kinerja perawat pelaksana dalam pendokumentasian asuhan keperawatan di ruang rawat inap Rumah Sakit Permata Bunda Kota Medan. Jenis penelitian ini adalah deksriptif analitik. Popilasi dalam penelitian ini adalah seluruh perawat yang bekerja di instalasi rawat inap yaitu sebanyak 106 perawat. Hasil uji regresi logistik didapatkan bahwa ada 3 variabel motivasi yang berpengaruh terhadap kinerja perawat di Rumah Sakit Permata Bunda yaitu supervisi $(\mathrm{p}=0,006)$, insentif $(\mathrm{p}=0,001)$, dan hubungan antar personal $(\mathrm{p}=0,019)$. Di sarankan kepada pimpinan rumah sakit untuk memperbaiki kualitas supervisi dan insentif untuk meningkatkan kinerja perawat dalam memberikan pelayanan

Kata Kunci: Motivasi ekstrinsik, kinerja, perawat

Abstract

Nurse performance is the implementation of professional duties carried out according to standards. Nurses not only carry out nursing care, but carry out nursing care documentation which is their performance. Implementing nurses did not understand the importance of documenting nursing care, this was evident from the documentation that was not equipped with nurses. The purpose of this study was to determine the effect of motivation on the performance of nurses in documenting nursing care in the inpatient room of Permata Bunda Hospital, Medan City. This type of research is analytical descriptive. Popilation in this study was all nurses who worked in inpatient installations, as many as 106 nurses. The logistic regression test results showed that there were 3 motivational variables that influence the performance of nurses in Permata Bunda Hospital, namely supervision ( $p=0.006$ ), incentives $(p=0.001)$, and interpersonal relationships $(p=0.019)$. It is recommended to hospital leaders to improve the quality of supervision and incentives to improve nurse performance in providing services.
\end{abstract}

Keywords: Extrinsic motivation, nurse, performance

Korespondensi : Wahyu Bima Saputra

Email : wahyubima081192@gmail.com 


\section{PENDAHULUAN}

Tenaga kesehatan dalam rumah sakit adalah setiap individu yang mengabdikan diri dalam bidang kesehatan yang dukung dengan pengetahuan serta keterampilan melalui proses pendidikan dalam bidang kesehatan yang untuk jenis tertentu memerlukan kewenangan dalam melakukan upaya kesehatan (1). Diantara berbagai tenaga kesehatan yang ada, perawat merupakan tenaga yang paling esensial dikarenakan perawat merupakan tenaga kesehatan yang paling banyak melakukan interaksi dengan pasien (2).

Kinerja perawat merupakan suatu aktivitas pengimplementasian suatu tugas, wewenang atau tanggung jawab dalam mencapai tujuan profesi dalam pelaksaanaan asuhan keperawatan dengan standar yang telah ditetapkan. Selain melakukan asuhan keperawatan langsung terhadap pasien, kinerja dari perawat ialah melaksanakan pendokumentasian asuhan keperawatan (3).

Dokumentasi keperawatan merupakan salah satu alat ukur untuk mengetahui, memantau, dan menyimpulkan penyelenggaraan asuhan keperawatan yang ada dirumah sakit (4). Seperti yang diketahui tujuan dari dokumentasi asuhan keperawatan sebagai komunikasi, diantaranya sebagai koordinasi, mencegah informasi berulang, peminimalkan kesalahan, meningkatkan penerapan asuhan keperawatan dan sebagai sarana perlindungan hukum bagi perawat jika terjadi gugatan di pengadilan sebagai mana yang sudah tercantum dalam dalam UndangUndang Nomor 38 Tahun 2014 tentang keperawatan.(5)

Potter \& Perry menyatakan bahawa ciri-ciri dokumentasi asuhan keperawatan yang baik ialah berdasarkan fakta (factual basis), akurat (accuracy), lengkap (completeness), ringkas (concoseness), terorganisir (organization), waktu yang tepat (time liness), dan bersifat mudah dibaca (legability) (6). Hal tersebut menjadi penting karena akurasi dan kelengkapan data dokumentasi keperawatan selain dapat meningkatkan mutu asuhan keperawatan, juga dapat menghindari kesalahan pembacaan, kesalahan penilaian dan kesalahan penentuan intervensi yang dapat membahayakan nyawa klien. Maka dari itu penting untuk meningkatkan kinerja perawat dalam hal asuhan keperawatan dan dokumentasi keperawatan (7).

Beberapa hal yang mempengaruhi kinerja ialah faktor kemampuan (ability) dan faktor motivasi (motivation) (8). Menurut Robbins (Nursalam, 2014 ) menyatakan kinerja karyawan (employee perfomance) adalah tingkat dimana karyawan mencapai 
persyaratan-persyaratan pekerjaan. Penilaian kerja (performance appraisal) adalah proses yang mengukur kinerja karyawan. Penilaian pada umumnya mencakup aspek kualitatif dan kuantitatif dari pelaksanaan kerja (9). Penialaian kinerja berkenaan dengan seberapa baik seseorang melakukan pekerjaan yang ditugaskan atau yang diberikan (10).

Menurut survey awal yang dilakukan, kinerja perawat di instalasi rawat inap Rumah Sakit Permata Bunda Kota Medan masih belum baik. Hal ini dapat di lihat dari survey awal peneliti dengan mengobservasi 30 rekam medis asuhan keperawatan rawat inap tahun 2017 sebagai sampel. Ditemukan bahwa sebanyak 27 (90\%) asuhan keperawatan masih belum terisi dengan baik dan masih terdapat kekosongan pada form yang telah tersedia.

Berdasarkan hasil wawancara tertulis dengan beberapa perawat yang bekerja di instalasi rawat inap Rumah Sakit X, mereka mengatakan bahwa melakukan pendokumentasian itu memang tanggung jawab seorang perawat, tetapi melakukan asuhan keperawatan bagi mereka merupakan yang lebih utama dibandingkan dengan melakukan dokumentasi keperawatan. Selanjutnya, mereka mengatakan bahwa memiliki keterhambatan dalam melakukan pendokumentasian karena jumlah pasien yang sangat tinggi dan sebagai alternatif mereka hanya menulis kegiatan pada catatan atau intruksi dokter. Selanjutnya perawat mengatakan bahwa mereka jika melakukan tugasnya dengan baik tidak pernah mendapatkan penghargaan dari kepala ruangan dan bahwa semuanya sama bagi kepala ruangan tidak ada perbedaan antara satu perawat dengan perawat lainnya.

Selanjutnya, mereka juga mengatakan bahwa kepala ruangan hanya memeriksa tugas dan memberikan teguran jika ada perawat yang kurang baik melakukan asuhan keperawatan dan tidak memberikan pengarahan dan dukungan dalam pendokumentasian asuhan keperawatan. Serta tidaknya ada teguran langsung dari kepala ruangan kepada perawat pelaksana yang bertugas jika terjadinya ketidaklengkapan atau kekosongan pada form dokumentasi asuhan keperawatan.

Lingkungan kerja di Rumah Sakit X sudah cukup nyaman, fasilitas untuk melaksanakan dokumentasi sudah memadai alat tulis dan form asuhan keperawatan sudah menggunakan sistem check list sehingga memudahkan perawat untuk melakukan pencatatan. Hubungan antar tim perawat juga masih kurang dan perlu ditingkatkan 
terutama dalam melengkapi dokumentasi asuhan keperawatan.

Dalam memberikan asuhan keperawatan kepada pasien, perawat harus memiliki kemampuan dan motivasi untuk meningkatkan dan mendorong perawat memberikan pelayanan yang terbaik kepada pasien. Dengan adanya kemampuan dan motivasi, perawat akan terdorong untuk melakukan tugas-tugasnya dengan baik. Motivasi bersumber dari dorongan dalam diri maupun dari luar diri perawat (11). Herzberg (1959) menyatakan bahwa motivasi terbagi dua bagian,yaitu faktor Ekstrinsik dan Intriksik. Motivasi ekstrinsik meliputi : administrasi dan kebijakan, supervisi, insentif, hubungan antar personal dan kondisi kerja. Faktor intriksik meliputi : tanggung jawab, kemajuan, pekerjaan itu sendiri, pencapaian dan pengakuan (12).

Berdasarkan beberapa permasalahan yang ditemui pada Rumah Sakit X Kota Medan, maka peneliti tertarik untuk meneliti "Pengaruh Motivasi Ekstrinsik Terhadap Kinerja Perawat Pelaksana dalam Pendokumentasian Asuhan Keperawatan Keperawatan di Ruang Rawat Inap Rumah Sakit X Kota Medan Tahun 2018.

\section{METODE}

Jenis penelitian ini adalah penelitian analitik kuantitatif dengan desain penelitian cross sectional yang dilaksanakan di Rumah Sakit Umum Permata Bunda Kota Medan berlokasi di Jalan Sisingamangaraja no.7 Medan, dimulai dari Juni 2018 hingga Oktober 2018. Populasi dalam penelitian ini adalah perawat yang bekerja di instalasi rawat inap Rumah Sakit Umum Permata Bunda Kota Medan sebanyak 106 orang. Adapun penetapan sampel dalam penelitian ini menjadi 106 orang atau 100\% dari jumlah populasi. Hal ini dilakukan untuk mempermudah dalam pengolahan data dan untuk hasil pengujian yang lebih baik.

Analisis data dilakukan secara bertahap yaitu analisis univariat, bivarait dan multivarait. Analisis univariat ini dilakukan untuk menjelaskan karakteristik masingmasing variabel yang diteliti dengan menggunakan distribusi frekuensi dari masing-masing variabel yang diteliti (13).

Analisis bivariat dilakukan untuk mengetahui hubungan antara 2 variabel, yaitu variabel independen dan variabel dependen dalam penelitian ini dengan menggunakan analisis Kai Kuadrat (Chi Square). Selanjutnya, analisis multivariat dilakukan untuk mengetahui variabel independen mana yang paling berpengaruh dalam berkorelasi 
dengan variabel dependen. Analsis multivariat yang digunakan dalam penelitian ini adalah analisis Regresi logistic (14).

\section{HASIL PENELITIAN}

Berdasarkan hasil analisis dapat diketahui bahwa dari 106 responden yang diamati, mayoritas berjenis kelamin perempuan yaitu ada sebanyak 94 responden
$(88,7 \%)$, berumur $<30$ tahun yaitu ada sebanyak 50 responden $(47,2 \%)$, dengan tingkat pendidikan D3 keperawatan yaitu ada sebanyak 79 responden $(74,5 \%)$, sudah menikah yaitu sebanyak 72 responden $(67,9 \%)$, dan sudah bekerja lebih dari lima tahun yaitu ada sebanyak 25 responden $(61,0)$.

Tabel 1.Distribusi Frekuensi Berdasarkan Data Karakteristik Responden

\begin{tabular}{|c|c|c|c|}
\hline No & Variabel & $\mathbf{n}$ & $\%$ \\
\hline \multirow[t]{4}{*}{1} & Jenis Kelamin & & \\
\hline & Perempuan & 94 & 88,7 \\
\hline & Laki-laki & 12 & 11,3 \\
\hline & Total & 106 & 100 \\
\hline \multirow[t]{5}{*}{2} & Kelompok Umur & & \\
\hline & $<30$ Tahun & 50 & 47,2 \\
\hline & 30-50 Tahun & 46 & 43,4 \\
\hline & $>50$ Tahun & 10 & 9,4 \\
\hline & Total & 106 & 100 \\
\hline \multirow[t]{6}{*}{3} & Pendidikan & & \\
\hline & D3 & 79 & 74,5 \\
\hline & Keperawatan & 6 & 5,7 \\
\hline & D4 Kebidanan & 8 & 7,5 \\
\hline & $\begin{array}{l}\text { S1 Keperawatan } \\
\text { SPK }\end{array}$ & 13 & 12,3 \\
\hline & Total & 106 & 100 \\
\hline \multirow[t]{5}{*}{5} & Status & & \\
\hline & Perkawinan & 72 & 67,9 \\
\hline & Menikah & 34 & 32,1 \\
\hline & Belum Menikah & & \\
\hline & Total & 106 & 100 \\
\hline \multirow[t]{4}{*}{7} & Lama Bekerja & & \\
\hline & $\leq 5$ Tahun & 16 & 39,0 \\
\hline & $>5$ Tahun & 25 & 61,0 \\
\hline & Total & 41 & 100 \\
\hline
\end{tabular}

Berdasarkan hasil analisis chi square diperoleh variabel supervisi, insentif, dan hubungan antar personal mempunyai nilai $\mathrm{p}<\alpha(0,05)$. Maka dapat disimpulkan bahwa variabel supervisi, insentif, dan hubungan antar personal memiliki hubungan yang signifikan dengan variabel dependen motivasi kerja. 
Tabel 2. Hubungan Motivasi Ekstrinsik dengan Kinerja Perawat

\begin{tabular}{lc}
\hline Variabel & p value \\
\hline Administrasi dan Kebijakan & 0,052 \\
Supervisi & 0,021 \\
Insentif & 0,001 \\
Hubungan Antar Personal & 0,046 \\
Kondisi Kerja & 0,301 \\
\hline
\end{tabular}

Analisis multivariat adalah analisis yang bertujuan untuk mengetahui besar pengaruh dari beberapa variabel independen terhadap variabel dependen secara bersamaan. Variabel yang dapat masuk ke tahap multivariat adalah variabel yang pada saat analisis bivariatnya memiliki nilai $\mathrm{p}<0,25$. Berdasarkan hasil analisis, dipeoleh kedua variabel memiliki nilai $\mathrm{p}<0,25$ maka selanjutnya dapat dilanjutkan ke tahap multivariat (7).

Tabel 3. Pengaruh Motivasi Ekstrinsik dengan Kinerja Perawat

\begin{tabular}{cccc}
\hline Variabel & p value & OR & $\begin{array}{c}\text { Interval Kepercayaan } \\
\mathbf{( 9 5 \% )}\end{array}$ \\
\hline Administrasi dan Kebijakan & 0,251 & 0,201 & $0,461-1,616$ \\
Supervisi & 0,006 & 4,143 & $0,527-11,327$ \\
Insentif & 0,001 & 5,004 & $1,122-18,001$ \\
Hubungan Antar Personal & 0,019 & 3,059 & $0,922-7,078$ \\
\hline
\end{tabular}

\section{PEMBAHASAN}

Dari hasil analisis menunjukkan bahwa hanya variabel supervisi, insentif, dan hubungan antar personal yang memilki nilai $\mathrm{p}<\alpha \quad(0,05)$, artinya variabel supervisi, insentif, dan hubungan antar personal memilki pengaruh yang signifikan terhadap variabel motivasi kerja perawat. Selanjutnya, pada nilai Odds Ratio (Exp B) dari variabel supervisi $(4,143)$, insentif $(5,004)$, dan hubungan antar personal $(3,059)$, hal ini bermakna bahwa supervisi yang baik akan dapat meningkatkan kinerja perawat sebesar 4 kali lebih tinggi dibandingkan dengan kompetensi supervisi yang tidak baik. Pada insentif yang dinilai baik akan dapat meningkatkan kinerja perawat sebesar 5 kali lebih tinggi dibandingkan dengan insentif yang tidak baik. Selanjutnya, pada hubungan antar personal perawat yang baik akan dapat meningkatkan kinerja perawat 3 kali lebih tinggi dibandingkan dengan hubungan antar personal yang tidak baik.

Hasil ini sejalan dengan Indri (2014) yang menyimpulkan bahwa lebih dari separuh (55\%) perawat pelaksana memiliki kinerja yang kurang baik dan kurang dari separuh $(45 \%)$ perawat pelaksana memiliki kinerja yang baik di Ruangn Rawat Inap RSUD dr. Rasidin Padang tahun 2014. Faktor motivasi yang mempengaruhi kinerja meliputi kebutuhan fisiologi, kebutuhan keamanan, kebutuhan sosial, kebutuhan penghargaan dan kebutuhan aktualisasi diri. Faktor yang paling berpengaruh ialah faktor aktualisasi diri, sebanyak $60 \%$ perawat memiliki motivasi rendah (15). 
Penelitian lain yang dilakukan oleh Machron (2017) di ruang inap Rumah Sakit Umum dr. Drajat Prawinegara kota Serang. Hasil penelitian menunjukkan hasil yang signifikan dengan indikator motivasi intrinsik yaitu meliputi tanggung jawab, penghargaan, pekerjaan dan pengembangan. Begitu juga dengan motivasi ekstrinsik yang juga berpengaruh terhadap kinerja perawat yang meliputi gaji, kebijakan, hubungan kerja, lingkungan kerja dan supervisi. Untuk indikator variabel kinerja meliputi kualitas kerja dan disiplin kerja. Penelitian ini menyimpulkan bahwa pengaruh motivais intrinsik dan ekstrinsik terhadap kinerja perawat rendah. Motivasi intrinsik yang besar pengaruhnya terhadap peningkatan kinerja adalah tanggung jawab. Sedangkan, motivasi ekstrinsik yang besar pengaruhnya terhadap peningkatan kinerja perawat adalah hubungan kerja dan lingkungan kerja (16).

Penelitian lain yang dilakukan oleh Dwi Nurseto (2018) yang dilakukan di ruang rawat inap Rumah Sakit Umum Daerah Ambarawa. Kesimpulan dari hasil penelitiannya menunjukkan bahwa ada pengaruh yang signifikan kepuasan perawat terhadap kelengkapan dokumentasi asuhan keperawatan. Kepuasan perawat yang baik meningkatkan peluang pendokumentasian asuhan keperawatan 2 kali lebih baik, sehingga semakin baik kepuasan perawat yang diperoleh semakin baik pula pendokumentasian asuhan keperawatan oleh perawat (17).

Selanjutnya penelitian yang lakukan oleh Agustina (2018) di Rumah Sakit Umum Deli Serdang. Bahwa tanggung jawab, prestasi, hasil kerja, gaji, status dan prosedur kerja berpengaruh secara signifikan terhadap kinerja, sedangkan kemungkinan pengembangan dan hubungan kerja perawat tidak berpengaruh terhadap kinerja perawat di ruang rawat inap di Rumah Sakit Umum Daerah Deli Serdang (18). Berdasarkan hasil penelitian maka perlu dilakukan upaya meningkatkan kinerja perawat dengan melaksanakan asuhan keperawatan yang didukung dengan SOP yang baku, membuat SOP asuhan keperawatan sesuai dengan tugas dan fungsi perawat, membuat SOP asuhan keperawatan sesuai dengan karakteristik atau jenis penyakit pasien dan kepala keperawatan harus mensosialisasikan SOP asuhan keperawatan yang berlaku kepada seluruh perawat ruang rawat inap (19).

Menurut Nopitasari dan Krisnandi (2018), semakin kuat motivasi intrinsik di dalam diri karyawan, maka semakin kuat keinginan karyawan tersebut untuk melaksanakan pekerjaannya dengan baik, sehingga semakin terdorong perilaku karyawan tersebut untuk diarahkan sesuai dengan standar kinerja dan tujuan perusahaan (20).

\section{KESIMPULAN DAN SARAN}

Terdapat pengaruh yang signifikan dari seluruh variable, adapun variabel Supervisi yang baik akan dapat meningkatkan kinerja perawat sebesar 4 kali lebih tinggi dibandingkan dengan supervisi yang tidak baik. Insentif yang dinilai baik akan dapat meningkatkan kinerja perawat sebesar 5 kali lebih tinggi dibandingkan dengan insentif yang tidak baik. Hubungan antar personal perawat yang baik akan dapat meningkatkan kinerja perawat 3 kali lebih 
tinggi dibandingkan dengan hubungan antar personal yang tidak baik.

Disarankan kepada pimpinan Rumah Sakit agar memperbaiki kualitas supervisi, dan menambah insentif, agar dapat meningkatkan kinerja perawat sehingga nantinya akan berdampak pada kualitas pelayanan yang lebih baik lagi.

\section{DAFTAR PUSTAKA}

1. American Nurses Association, (2013). Standards of professional nursing practice (Edisi ke-2). Silver Spring, MD: ANA

2. Undang-Undang Republik Indonesia No. 36 tahun 2009 tentang kesehatan.

3. Edison, E., Yohny, A., \& Imas, K. (2016). Manajemen sumber daya manusia. Bandung: Alfabeta.

4. Suprapto, I., \& Wahid, A. (2012). Dokumentasi Proses Keperawatan. Yogyakarta: Nusa Medika.

5. Undang-Undang Republik Indonesia Nomor 38 Tahun 2014 Tentang Keperawatan

6. American Nurses Association. (2015). Standards Of Professional Nursing Practice. (Edisi ke-3). Silver Spring, MD: ANA

7. Mangkunegara. (2014). Manajemen sumber daya manusia perusahaan. Bandung: Remaja Rosdakarya

8. Mangkunegara. (2014). Evaluasi kinerja SDM. Bandung: Reflika Aditama

9. Nursalam. Manajemen Keperawatan Aplikasi Dalam Praktik Keperawatan Profesional (Edisi Kelima). Jakarta: Salemba Medika. 2014.
10. Retyaningsih, Ida Yanti. Hubungan Karakteristik Perawat, Motivasi, Dan Supervisi Dengan Kualitas Dokumentasi Proses Asuhan Keperawatan. 2014;1(2): 107-114

11. Mangkunegara. (2014). Manajemen sumber daya manusia perusahaan. Bandung: Remaja Rosdakarya.

12. Mangkunegara. (2014). Evaluasi kinerja SDM. Bandung: Reflika Aditama

13. Sugiyono. (2015). Statistik untuk Penelitian. Bandung: Alfabeta

14. Gulo, W. (2013). Metodologi penelitian. Jakarta: Gramedia Widiasarana Indonesia.

15. Indri Ramadini \& Erni Jasmita. Hubungan Motivasi Dengan Kinerja Perawat Pelaksana Di Ruangan Rawat Inap Rsud Dr. Rasidin Padang. 2015;11(1):86-101.

16. Machron $\mathrm{Ch}$, Achmad. Pengaruh Motivasi Terhadap Kinerja Perawat. 2017;4(4): 201-209.

17. Nurseto, Dwi. Pengaruh Kepuasan Perawat Terhadap Kelengkapan Dokumentasi Asuhan Keperawatan Di Ruang Rawat Inap Rsud Ambarawa. 2018;3(1): 1-10

18. Agustina Susanti , Megawati \&Yuniati. Pengaruh Motivasi Kerja Terhadap Kinerja Perawat Di Ruang Rawat Inap Rumah Sakit Umum Daerah Deli Serdang Tahun 2018. 2019;3(2) 165-174

19. Gibson JL, Wahid D. Struktur Organisasi dan Manajemen. Jakarta: Pusat Kajian Ekonomi Kesehatan FKM Universitas Indonesia; 2002 
20. Nopitasari, E. dan H. Krisnandi. Pengaruh Gaya Kepemimpinan Demokratis, Motivasi Intrinsik dan Disiplin Kerja terhadap Kinerja Karyawan PT Pangansari Utama Food Industry.2018;14(1): 15-30. 